\title{
Ecofriendly Remediation of Pulp and Paper Industry Wastewater by Electrocoagulation and Its Application in Agriculture
}

\author{
Dushyant Kumar, Vivek Kumar Gaurav, Chhaya Sharma* \\ Environmental Research Laboratory, Department of Paper Technology, Indian Institute of Technology Roorkee, Saharanpur \\ Campus, Saharanpur, India \\ Email: dkumar23evs@gmail.com, gaurav.vivek08@gmail.com, *Chhaya1964@rediffmail.com
}

How to cite this paper: Kumar, D., Gaurav, V.K. and Sharma, C. (2018) Ecofriendly Remediation of Pulp and Paper Industry Wastewater by Electrocoagulation and Its Application in Agriculture. American Journal of Plant Sciences, 9, 2462-2479.

https://doi.org/10.4236/ajps.2018.912178

Received: September 29, 2018

Accepted: November 23, 2018

Published: November 26, 2018

Copyright ( $) 2018$ by authors and Scientific Research Publishing Inc. This work is licensed under the Creative Commons Attribution International License (CC BY 4.0).

http://creativecommons.org/licenses/by/4.0/

\begin{abstract}
In the present study pulp and paper industry effluent was treated with the help of aluminum electrode using electrocoagulation (EC) process with feasible sludge management. The influences of $\mathrm{pH}$, time, current density and electrolytes dose were investigated and optimum conditions were established to reduce the maximum amount of Chemical Oxygen Demand (COD) and color. At optimum conditions $70 \%$ of $\mathrm{COD}$ and $98 \%$ of color were removed. Additionally, the behavior of electrolytes $\left(\mathrm{NaCl}\right.$ and $\left.\mathrm{Na}_{2} \mathrm{SO}_{4}\right)$ was determined; it has shown that $\mathrm{Na}_{2} \mathrm{SO}_{4}$ results in the generation of less secondary pollutants than that $\mathrm{NaCl}$ and thereby could be used as better replacement in paper industries for electrocoagulation mediated treatment of wastewater. The residual amount of operational parameters in EC treated water was compared to the World Health Organization (WHO) and Central Pollution Control Board ( $\mathrm{CPCB})$ of India. It was found to be safe for utilization in irrigation. Furthermore, sludge produced during the EC process has been analyzed for physicochemical characteristics. To understand the physical and elemental phases of sludge, the analytical technique such as field emission electron microscope coupled with energy dispersive spectroscopy has been used to find out the possible management alternative.
\end{abstract}

\section{Keywords}

Pulp and Paper Wastewater, Electrocoagulation, Reuse, Irrigation, Sustainable Sludge Management

\section{Introduction}

The production of paper by pulp and paper industries requires a tremendous 
volume of fresh water $\left(10-110 \mathrm{~m}^{3}\right.$ per tonne) subsequently generating the high volume of effluent therefore considered to be one of the most polluting industries [1]. This industry generates wastewater which has a large amount of total solids (TS), color, numerous recalcitrant compounds and increased chemical oxygen demand (COD) [2]. More than 250 chemicals compounds have been acknowledged in effluents generated at different stages of papermaking including phenols and Chlorophenols compounds, resin and fatty acid, lignin and its derivatives [3] [4] [5]. If this effluent is directly discharged into the environment it will lead to significant environmental damage such as loss of environmental aesthetics, the extensive negative effect on aquatic animals, likewise seriously affecting the terrestrial ecosystem [6] [7] [8] [9]. The pulp and paper industry wastewater has been listed in the "red category" by the Ministry of Environment Forest and Climate Change (MOEFCC), India CPCB, India which indicates the severity of associated pollution risk [10]. Thus, there is an urgent need of the suitable treatment for wastewater generated by pulp and paper industry. The Indian paper industries adopted pre, primary and secondary treatment facility to treat the wastewater, but they have failed to achieve complete degradation of recalcitrant compounds and attain the satisfactory level of treatment [5] [6]. There are various technologies like, aerobic and anaerobic, adsorption, advanced oxidation, membrane separation process and chemical coagulation which can be used for the removal of refractory chemicals [11]-[16]. However, these methods have their own limitations such as high cost, high chemical consumption, longer retention time, and chances of secondary pollution. Additionally, biochemical methods cannot be applied to treat paper industry wastewater due to the limitation of lower biodegradability [17] [18]. Recently, Electrocoagulation (EC) method attracted the researcher's attention as an alternative with some attractive factors which make EC process one of the most important technologies for treating the wastewater. EC uses simple equipment with ease of automation while no or very few chemicals are required to be added to this process [19] [20] [21] [22] [23]. Additionally, $\mathrm{O}_{2}$ and $\mathrm{H}_{2}$ bubbles are formed during the process which improves the separation efficiency by electro-flotation and it can handle a wide variety of pollutants [24] [25] [26]. In EC method three main stages are involved 1) Electrolytic reaction at anode and cathode surfaces 2) Formation of coagulant in solution 3) Suspended pollutant matter gets adsorbed on coagulant and gets removed by settling and flotation process. In EC, generally anode releases positive metal hydroxide ions at desired $\mathrm{pH}$ [21] [22] [27]. In this study aluminum was used as the electrode and the mechanism of reaction during the EC process for both anode and cathode are represented below:

$$
\begin{gathered}
\text { Anode: } \mathrm{Al} \rightarrow \mathrm{Al}^{3+}+3 \mathrm{e}^{-} \\
\text {Cathode: } 3 \mathrm{H}_{2} \mathrm{O}+3 \mathrm{e}^{-} \rightarrow \frac{3}{2} \mathrm{H}_{2}+3 \mathrm{OH}^{-}
\end{gathered}
$$

Under high $\mathrm{pH}$ condition, $\mathrm{H}_{2}$ produced $\mathrm{OH}$ ions at cathode [22]. 


$$
2 \mathrm{Al}+6 \mathrm{H}_{2} \mathrm{O}+2 \mathrm{OH}^{-} \rightarrow 2 \mathrm{Al}(\mathrm{OH})_{4}^{-}+3 \mathrm{H}_{2}
$$

In $\mathrm{EC}, \mathrm{Al}^{3+}$ and $\mathrm{OH}^{-}$ions were generated at electrode and they react to form various monomeric species such as $\mathrm{Al}(\mathrm{OH})^{2+}, \mathrm{Al}(\mathrm{OH})_{4}^{+}, \mathrm{Al}_{2}(\mathrm{OH})_{2}^{4+}, \mathrm{Al}(\mathrm{OH})_{4}^{-}$ and polymeric species such as $\mathrm{Al}_{6}(\mathrm{OH})_{15}^{3+}, \mathrm{Al}_{7}(\mathrm{OH})_{17}^{4+}, \mathrm{Al}_{8}(\mathrm{OH})_{20}^{4+}$, $\mathrm{Al}_{13} \mathrm{O}_{4}(\mathrm{OH})_{24}^{7+}, \mathrm{Al}_{13}(\mathrm{OH})_{34}^{5+}$ which finally transformed into $\mathrm{Al}(\mathrm{OH})_{3(\mathrm{~s})}$ according to complex precipitation kinetics [21] [28] [29].

$$
\mathrm{Al}^{3+}+3 \mathrm{H}_{2} \mathrm{O} \rightarrow \mathrm{Al}(\mathrm{OH})_{3(\mathrm{~s})}+3 \mathrm{H}^{+}
$$

These $\mathrm{Al}(\mathrm{OH})_{3(\mathrm{~s})}$ flocs produced during the treatment, have the larger surface area, which strengthen the removal of pollutants from wastewater through adsorption or precipitation. $\mathrm{Al}(\mathrm{OH})_{3(\mathrm{~s})}$ have the neutral characteristic which function as a coagulating agent in the reaction vessel for the suspended and contaminated particle. Finally, these flocs are separated from the treated wastewater without any difficulty by sedimentation or $\mathrm{H}_{2}$ floatation [22] [28]. In recent years, the approach of EC treatment process has been extensively used for the treatment of various types of effluent including dye containing effluent [21], lignin and phenol [29], Oil refinery wastewater [30], textile effluent [22], pharmaceutical industry effluent [20], recalcitrant and dissolved organic matter from paper industry effluent [12]. The previous literature has widely discussed the operating parameters and associated physical and chemical reaction to complete the process but, physicochemical characterization of sludge and management of sludge has been studied poorly. The production of sludge is an integral part of EC process and considered as a waste material, therefore pulp and paper mills in India get rid of this sludge by landfilling practices [31]. However, such practices of land filling are associated with potential risk of polluting the soil, water table and entire ecosystem. From the environmental perspective, the disposal of sludge becomes a challenging task which needs immediate sustainable management. As per our best knowledge, there have been studies which have categorically focused on the settling characteristics and sludge volume index of electrocoagulation sludge, whereas there has been a consistent lack of research efforts in the direction of physicochemical characteristics, and elemental analysis of EC sludge investigation [32] [33] [34]. Similarly, very few studies have been conducted on the removal of biochemical oxygen demand (BOD), chemical COD, and total organic carbon (TOC) evaluation of wastewater. The studies related to sludge management and treated water reused also less reported. The objectives of the present study were to develop the optimum conditions for the treatment of pulp and paper industry wastewater and sludge management. To investigate the optimum conditions of treatment, COD and color were taken into consideration and the resulting optimum conditions were utilized to determine the BOD, TOC, total dissolved solids (TDS) and conductivity of wastewater to find out the option to reuse EC treated water in irrigation and sludge for further application. 


\section{Materials and Methods}

\subsection{Wastewater Sample Collection and Characterization}

The effluent sample was procured from the nearby paper industry after the primary treatment. The industry used OCEpHH bleaching sequence for the production of pulp and paper. Collected sample was stored below $4^{\circ} \mathrm{C}$ in the laboratory for further investigation. General characteristics of collected effluent are presented in Table 1. The evaluation of the study was performed on the basis of reduction in $\mathrm{COD}$ and color at the various $\mathrm{pH}$, current density, time, and dose of electrolytes. Further, at the optimum conditions, the samples were analyzed using different environmental parameters such as $\mathrm{pH}, \mathrm{BOD}_{3}$, COD TOC, color, conductivity, TDS and sludge characterization as per standard methods [35]. The treatment efficiency was evaluated in terms of COD and color reduction percentage using the following equation:-

$$
\text { Treatment efficiency }(\%)=\frac{I_{0}-F_{t}}{I_{0}} \times 100
$$

where, $I_{0}=$ Initial value, $F_{t}=$ Final value at time $t$.

\subsection{Sludge Characterization}

The EC process completed within $30 \mathrm{~min}$ and after the completion of every run, a viscous mixture of semi liquid and solid was settled at the bottom while scum content was moved upwards at the top of reaction vessel. The sludge was collected after applying filter process, both sludge and scum were dried for three to four days at room temperature followed by oven drying in at $105^{\circ} \mathrm{C}$ until constant weight was obtained (Popular Model No. HAC405) and finally crushed in mortar pestle for further used. Field Emission Scanning Electron Microscope (FESSEM, MIRA3 TESCAN) coupled with energy dispersive X-ray spectrometry (AMETEK EDAX) was used to determine morphological characteristics and elemental analysis of sludge respectively.

\subsection{Electrocoagulation Unit}

The schematic diagram of batch scale laboratory experimental setup is shown in Figure 1. The EC experiment and electrodes configuration details are given in Table 2. The experimental unit was stirred with a magnetic stirrer at $100 \mathrm{rpm}$

Table 1. Characteristics feature of effluent collected from the paper industry.

\begin{tabular}{cc}
\hline Parameters (Unit) & Values $( \pm$ SD) \\
\hline $\mathrm{pH}$ & $7.7 \pm 0.02$ \\
$\mathrm{BOD}_{3}(\mathrm{mg} / \mathrm{L})$ & $180.54 \pm 4.70$ \\
$\mathrm{COD}_{(\mathrm{mg} / \mathrm{L})}$ & $584 \pm 3.62$ \\
$\mathrm{BOD}_{3} / \mathrm{COD}$ & $0.30 \pm \mathrm{NA}$ \\
$\mathrm{TOC}(\mathrm{mg} / \mathrm{L})$ & $216.44 \pm 3.54$ \\
$\mathrm{Color}(\mathrm{Pt}-\mathrm{Co} . \mathrm{units})$ & $1202 \pm 6.53$ \\
$\mathrm{TDS}(\mathrm{mg} / \mathrm{L})$ & $1686 \pm 10.58$
\end{tabular}




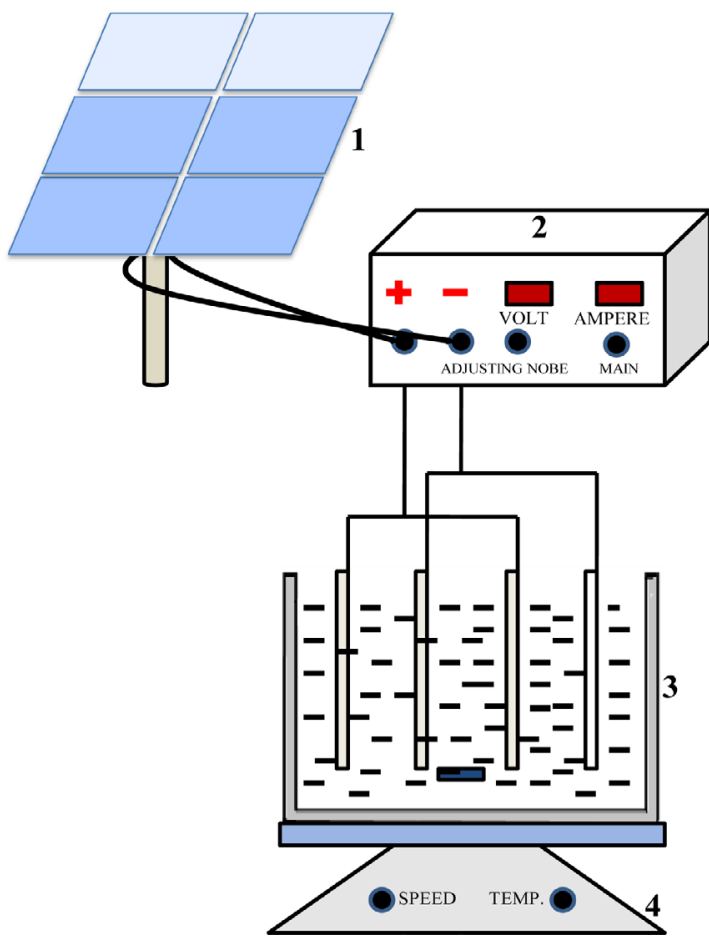

Figure 1. Laboratory scale experimental setup of the electrocoagulation unit (1-Solar panel, 2-Direct current supply and 3-Treatment vessel, consists of Anode and Cathode in mono-polar mode, magnetic-bead, and 4-Magnetic stirrer).

Table 2. Configuration detail of electrocoagulation unit: (i) electrode characteristics; (ii) reactor characteristics and (iii) optimized operating conditions.

\begin{tabular}{|c|c|}
\hline \multicolumn{2}{|c|}{ (i) Electrode characteristics } \\
\hline Cathode and anode material & Aluminum \\
\hline Shape & Rectangular \\
\hline Size $(L \times W)$ & $40 \times 70$ \\
\hline Numbers of electrode & 4 \\
\hline Plate arrangement & Parallel \\
\hline Connection mode & Mono-polar \\
\hline Effective area of the electrodes $\left(\mathrm{mm}^{2}\right)$ & 496 \\
\hline \multicolumn{2}{|c|}{ (ii) Reactor characteristics } \\
\hline Material & Plastic \\
\hline Mode & Batch \\
\hline Volume (ml) & 250 \\
\hline Used effluent volume (ml) & 250 \\
\hline Electrodes gap $(\mathrm{mm})$ & 10 \\
\hline Power supply & Direct current \\
\hline Voltage range $(\mathrm{V})$ & $1-12$ \\
\hline Current range $(\mathrm{A})$ & $0.25-1.75$ \\
\hline \multicolumn{2}{|c|}{ (iii) Optimized operating conditions } \\
\hline $\mathrm{pH}$ & 7.0 \\
\hline Cell voltage (V) & 4.2 \\
\hline Current density $\left(\mathrm{mA} / \mathrm{cm}^{2}\right)$ & 25.20 \\
\hline
\end{tabular}


for the uniform mixing of wastewater. Uniform and the continuous power supply are mandatory to achieve satisfactory result during wastewater treatment. India having 250 - 300 clear and sunny days in a year hence considered as a tropical country. So, it has huge solar energy potential which can be easily utilized as a source of power [36]. Moreover, Government of India promoting solar energy by initiating many schemes and subsidized the programme such as $\mathrm{Na}$ tional Solar Mission and several central financial assistance schemes and encourages the public to adopt green and clean energy approach. Photovoltaic (PV) is a most popular source of renewable energy, was used as a direct power source and connected to direct power supply because in EC method direct current (DC) is utilized [37]. Application of PV as a power source successfully applied in electrochemical method to treat various types of water and wastewater [38] [39] [40] [41]. It reduced the load and expenses of electricity, cost of equipment for converting the alternate current into direct current. Low maintenance cost, long life, and nonpolluting nature are positive factors of PV which make it a promising and safe alternative for wastewater treatment [42].

\section{Results and Discussion}

\subsection{Parameters Optimization}

Paper mill wastewater consists of the heavy organic load in terms of COD and color. The study was carried out for the optimization of different variables i.e. $\mathrm{pH}\left(5.0\right.$ - 9.0), time $(10-50 \mathrm{~min})$, current density $\left(5.04-25.20 \mathrm{~mA} / \mathrm{cm}^{-2}\right)$ and electrolyte dose $(0.5-2.0 \mathrm{~g} / \mathrm{L})$. All these parameters were determined on the basis of maximum COD and color removal.

\subsection{Effect of $\mathrm{pH}$}

The $\mathrm{pH}$ is one of the major parameters to determine the performance of the EC process [43] [44] [45]. The impact of $\mathrm{pH}$ was investigated for the elimination of COD and color; all other parameters were kept constant during this study. Reduction percentage of color and COD showed positive relation till the $\mathrm{pH}$ range of 5 to 7 . The highest COD (23\%) and color (42\%) removal was observed at $\mathrm{pH} 7$ (Figure 2). As the $\mathrm{pH}$ goes higher from neutral $\mathrm{pH} 7$, the reduction rate

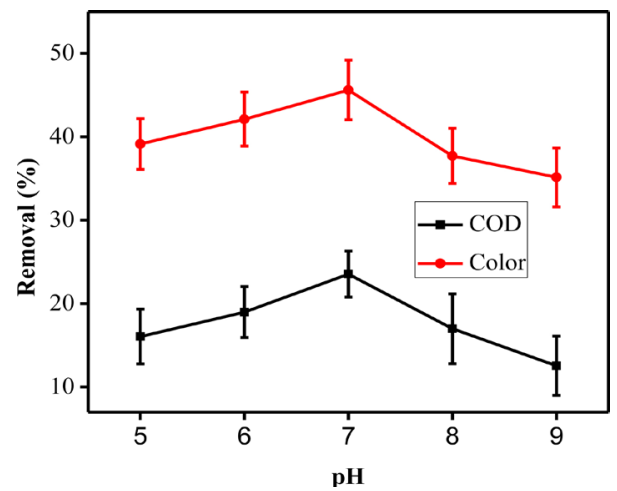

Figure 2. Effect of $\mathrm{pH}$ on removal of $\mathrm{COD}$ and Color (Conditions: Time $=10 \mathrm{~min}$; Current density $=5.04 \mathrm{~mA} / \mathrm{cm}^{2}$; Electrolyte dose $=0.5 \mathrm{~g} / \mathrm{L}$ and stirrer speed $100 \mathrm{rpm}$ ). 
of COD and color started declining and lowest color (35\%) and COD removal (12\%) was observed at $\mathrm{pH} 9$ (Figure 2). The higher COD and color removal at $\mathrm{pH} 7$ is observed to be due to the formation of aluminum hydroxide $\mathrm{Al}(\mathrm{OH})_{3}$ (Reaction 7). $\mathrm{Al}(\mathrm{OH})_{3}$ has a larger surface area and is amphoteric in nature which enhances the coagulation process. At $\mathrm{pH}$ higher than $8, \mathrm{Al}(\mathrm{OH})_{3}$ is converted to $\mathrm{Al}(\mathrm{OH})_{4}$ which suppresses the removal of COD and color and accounts for the lower percentage of COD and color removal at alkaline $\mathrm{pH}$ (Reaction no 8 to 10) [46].

Reaction for alkaline and acidic conditions:

For acid condition

$$
\begin{gathered}
\mathrm{Al} \rightarrow \mathrm{Al}^{3+}+3 \mathrm{e}^{-} \\
\mathrm{Al}^{3+}+3 \mathrm{H}_{2} \mathrm{O} \rightarrow \mathrm{Al}(\mathrm{OH})_{3}+3 \mathrm{H}^{+}
\end{gathered}
$$

For alkali condition

$$
\begin{gathered}
\mathrm{Al} \rightarrow \mathrm{Al}^{3+}+3 \mathrm{e}^{-} \\
3 \mathrm{H}_{2} \mathrm{O}+3 \mathrm{e}^{-} \rightarrow \frac{3}{2} \mathrm{H}_{2(\mathrm{~g})}+3 \mathrm{OH}^{-} \\
2 \mathrm{Al}+6 \mathrm{H}_{2} \mathrm{O}+2 \mathrm{OH}^{-} \rightarrow 2 \mathrm{Al}(\mathrm{OH})_{4}^{-}+3 \mathrm{H}_{2}
\end{gathered}
$$

Highest COD and Color removal was observed around $\mathrm{pH} 7$, where the buffering effect during EC also plays a significant role investigated by earlier authors [16] [22] [44] [47]. In this study, initial $\mathrm{pH}$ was adjusted at two acidic levels, $\mathrm{pH} 5$ and $\mathrm{pH} 6$ which rose to $\mathrm{pH} 6.73$ and $\mathrm{pH} 7.28$ respectively. In acidic condition, hydrogen ions were liberated at cathode which neutralized the $\mathrm{pH}$ of the aqueous solution in EC. This study, it was examined that initial basic pH 8 and 9 reduced to 7.88 and 8.38 , respectively due to the buffer reaction. In the basic environment such as at $\mathrm{pH} 8$ and 9, the hydroxide ions precipitate near anode which results in lowering of wastewater $\mathrm{pH}$. The water oxidation and chlorine production at the vicinity of the anode in basic wastewater treatment by EC process also helps in maintaining the $\mathrm{pH}$ around 7 [44] [48] [49].

\subsection{Effect of Current Density}

The effect of current density on the percentage removal of COD and color was studied with an initial COD (584 mg/L) and initial $\mathrm{pH} 7$ of solution (Figure 3 ). In this study, we observed that COD removal and color removal increased by increasing current density $5.04 \mathrm{~mA} / \mathrm{cm}^{2}$ to $25.20 \mathrm{~mA} / \mathrm{cm}^{2}$. When current density was varied from 25.20 to $35.28 \mathrm{~mA} / \mathrm{cm}^{2}$ the COD removal remained constant at around $58 \%$. However, the percentage of color removal showed positive relationship even after $25.20 \mathrm{~mA} / \mathrm{cm}^{2}$ current density. Percentage of color removal was approximately\% at $25.20 \mathrm{~mA} / \mathrm{cm}^{2}$ and minor reduction found to be up to $92 \%$ at $35.28 \mathrm{~mA} / \mathrm{cm}^{2}$ current density [49]. In the EC process the higher current density directly proportion to the formation of high coagulant and bubble which causes the high efficiency of the process. Additionally, when gas bubble density increases consequently the size of bubble reduce and enhance the upward floatation of bub- 
ble subsequent pollutant reduction and sludge settling increases [48] [50].

\subsection{Effect of Time on Treatment}

The effect of treatment durations (10 to $50 \mathrm{~min}$ ) on the percentage removal of COD and color with initial $\mathrm{pH}(7)$, current density $\left(25.20 \mathrm{~mA} / \mathrm{cm}^{2}\right)$ and electrolyte dosage $(0.5 \mathrm{~g} / \mathrm{L})$ and resultant finding are graphically presented in Figure 4. Initially, in the experiment the color gradually turns cloudy which may be due to production of $\mathrm{Al}$ ions at anode. At the end of the first set of experiment i.e. after $10 \mathrm{~min}$, there was a significant percentage removal of color (Figure 4). The color removal after 20 min of process time is observed to be about $90 \%$ and the highest percent of color removal was noted on $40 \mathrm{~min}$ of experiment duration. However, no significant change in color removal was observed from $40 \mathrm{~min}$ to 50 min time interval (Figure 4). With the progression of time the $\mathrm{Al}$ ions which were produced initially and imparted cloudy color at the anode were removed by coagulation method in the form of sludge [46]. The percentage of COD removal has

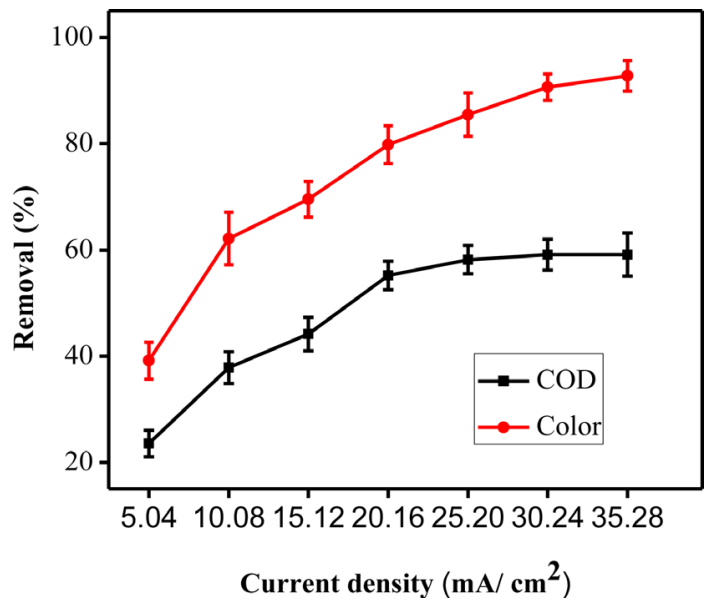

Figure 3. Effect of current density on the removal of COD and color (Conditions: $\mathrm{pH}=7$; Time $=10 \mathrm{~min}$; Electrolyte dose $=0.5 \mathrm{~g} / \mathrm{L}$; and stirring speed $100 \mathrm{rpm}$ ).

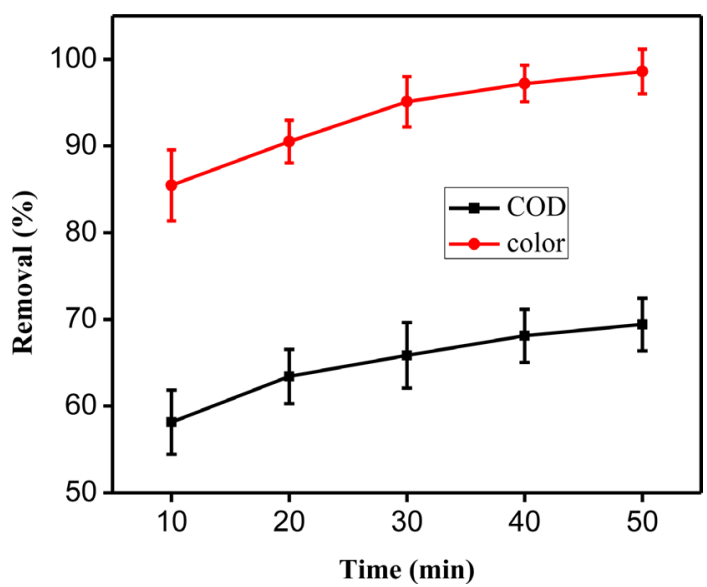

Figure 4. Effect of time on the percentage removal of COD and color (Conditions: $\mathrm{pH}=$ 7; Current density $=25.20 \mathrm{~mA} / \mathrm{cm}^{2}$; Dose of electrolyte $=0.5 \mathrm{~g} / \mathrm{L}$; and stirring speed 100 rpm). 
progressively increased from $10 \mathrm{~min}$ to $40 \mathrm{~min}$ (Figure 4). After 40 minutes of time duration, no effect on COD removal percentage was observed (Figure 4). COD removal was $58 \%$ on 10 min and it reached to $68 \%$ in just next 30 minutes which can be attributed to the fact that, $\mathrm{Al}(\mathrm{OH})_{3(5)}$ dissolved in solution and formed hydroxo complexes $[\mathrm{Al}(\mathrm{OH}) \mathrm{m}]^{\mathrm{n}-3}[51]$. These hydroxyl ions neutralize the pollutants which favor the aggregation and settling of suspended particle and dissolved organic matter resultant higher COD and color reduction [30]. The trend of COD shows no significant removal after $40 \mathrm{~min}$. Therefore $40 \mathrm{~min}$ of reaction time was considered as optimum and was used for further study. It is supported by earlier findings [43] [46] [52] [53].

\subsection{Effect of the Supporting Electrolytes}

Electrolytes are generally used and mixed in the aqueous solutions to enhance its conductivity [54]. In this study we have investigated the effect of two electrolytes $\left(\mathrm{Na}_{2} \mathrm{SO}_{4}\right.$ and $\left.\mathrm{NaCl}\right)$ on percentage of $\mathrm{COD}$ and color removal. The time duration of experiment, $\mathrm{pH}$ and current density was optimized initially as $40 \mathrm{~min}, 7$ and $25.20 \mathrm{~mA} / \mathrm{cm}^{2}$, respectively. It was observed that COD removal percentage increased as we increased the electrolyte (in both: $\mathrm{NaCl}$ and $\mathrm{Na}_{2} \mathrm{SO}_{4}$ ) dose from 0.5 $\mathrm{g} / \mathrm{L}$ to $1.0 \mathrm{~g} / \mathrm{L}$ (Figure 5). Electrolyte application at the rate of $1.0 \mathrm{~g} / \mathrm{L}$ for $\mathrm{NaCl}$ and $\mathrm{Na}_{2} \mathrm{SO}_{4}$ results in approximately $70 \%$ and $71 \%$ COD removal respectively (Figure 5). The increase in COD removal percentage on the application of electrolytes is due to rapid motion of ions in the solution. However, on enhancing electrolyte dose from $1.0 \mathrm{~g} / \mathrm{L}$ to $2.0 \mathrm{~g} / \mathrm{L}$ no significant change in COD removal was observed (Figure 5) [50]. On the other hand, on decreasing the value of electrolyte to $0.5 \mathrm{~g} / \mathrm{L}$ of $\mathrm{NaCl}$ and $\mathrm{Na}_{2} \mathrm{SO}_{4}$ about $98.5 \%$ and $98 \%$ of color removal was found and no significant change was achieved on the addition of extra amount of electrolyte (Figure 5). On addition of $\mathrm{NaCl}$ as an electrolyte in aqueous solution, it converted into ions of chloride $\left(\mathrm{Cl}^{-}\right.$and $\left.\mathrm{OCl}^{-}\right)$at anode [55].

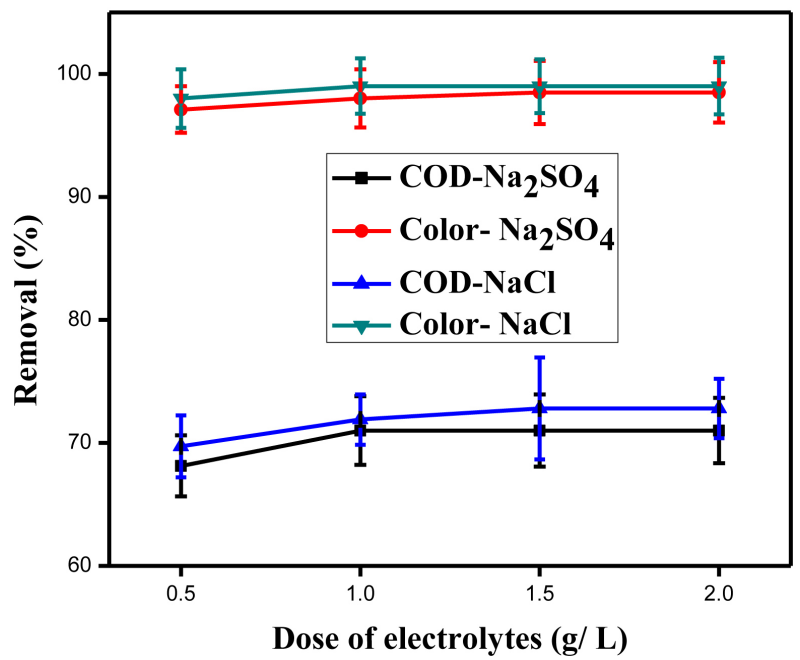

Figure 5. Effect of dose of electrolytes on the percentage removal of COD and Color (Conditions: $\mathrm{pH}=7$; current density $=25.20 \mathrm{~mA} / \mathrm{cm}^{2}$; time $=40 \mathrm{~min}$; and stirring speed $100 \mathrm{rpm})$. 
This chloride plays a crucial role in oxidation reaction which results in degradation of organic matter [56]. Some researchers [44] [57] [58] have reported that $\mathrm{Cl}^{-}$ions may react with lignin and phenols present in pulp and paper industry effluent and produce oxidizable chlorolignin and chloro-compounds. After discharging these chlorolignin \& chlorocompounds in the freshwater ecosystem they cause harmful effects on the fauna and flora [17]. To the best of our knowledge, there is no harmful chemistry is associated with the use of $\mathrm{Na}_{2} \mathrm{SO}_{4}$ therefore; $\mathrm{Na}_{2} \mathrm{SO}_{4}$ may be a good possible option instead of $\mathrm{NaCl}$ as an electrolyte. Nevertheless, this observation requires to be proven by experimental evidence and thus this constitutes the future analysis in this direction.

\subsection{Biodegradability Study}

Biodegradability of the effluent (BOD/COD) has been measured at optimum conditions. During the treatment the biodegradability of effluent increased progressively and reached maximum at around $40 \mathrm{~min}$ by electro-coagulation. After $40 \mathrm{~min}$ of treatment there is no improvement in the biodegradability index. Therefore, $40 \mathrm{~min}$ was assumed to be the optimum time duration for the biodegradability of effluent. In present study it was observed that the biodegradability increased up to 0.41 within 40 min of electrocoagulation process. As reported by previous author, the sample of wastewater considered ease to biodegradation when the value $\mathrm{BOD} / \mathrm{COD}$ ratio reaches in the range of $(0.4-0.8)$ and the treatment process mentioned as effective for the destruction of pollutants [55] [59].

\subsection{Reuse Option for EC Treated Water}

According to Table 3, all residual operating parameters were in the prescribed range of the World Health Organization (WHO) and CPCB standard that ensure the reusability of treated water for irrigation purposes. This EC process and its applications are environmentally sustainable and economically viable.

\section{Sludge Characteristics and Its Management}

Characterization of sludge involves the explanation of sludge behavior during the treatment and disposal but improper dumping of EC sludge may contribute main consequences such as leachate, odour, transportation, escalating cost and

Table 3. Comparison of studied treated water quality with $\mathrm{CPCB}$ and WHO wastewater reuse standards for irrigation in agriculture land [60].

\begin{tabular}{cccc}
\hline Characteristics & Treated water & PL $^{*}(\mathrm{CPCB})$ & PL $^{*}$ (WHO) \\
\hline $\mathrm{pH}$ & 7.9 & $5.5-9.0$ & $6-9$ \\
$\mathrm{BOD}(\mathrm{mg} / \mathrm{L})$ & 72 & 100 & 200 \\
$\mathrm{COD}(\mathrm{mg} / \mathrm{L})$ & 175 & $\mathrm{NA}$ & 500 \\
$\mathrm{TDS}(\mathrm{mg} / \mathrm{L})$ & 995 & $\mathrm{NA}$ & 1500 \\
Color $($ Pt-Co. Units) & 24 & $\mathrm{NA}$ & $\mathrm{NA}$ \\
Conductivity $(\mathrm{mS})$ & 2.648 & $\mathrm{NA}$ & $\mathrm{NA}$ \\
Aluminum $(\mathrm{mg} / \mathrm{L})$ & 2.53 & $\mathrm{NA}$ & 5.0 \\
\hline
\end{tabular}

${ }^{\star} \mathrm{PL}=$ Permissible Limit. 
negative effect on the environment [61]. As for environmental consideration only, sludge disposal is not necessary but a need of sustainable sludge management is the necessity. So, analysis of the sludge and an integrative approach practice became a necessity to understand its properties and management. In this study main focus on the characterization which provides the valuable information to alternative approaches for reusing it in agriculture land applications. The major physiochemical characteristics are given in Table 4 . The sludge produced in EC process found to be dark brown in color and average moisture content was $15 \%$, less moisture content will be helpful in reduced weight and handling properties of sludge. The $\mathrm{pH}$ was found to be basic in nature 7.90 this may be due to the basic nature of paper mill effluent and buffering effect of EC process. This could be beneficial for agriculture soil which has low $\mathrm{pH}$ value somewhere in Indian subcontinent. The higher organic content in sludge is working as a soil conditioner and enhances the soil fertility [62]. The volume of sludge in $\mathrm{g} / \mathrm{L}$ was measured on dry basis formed by $1 \mathrm{~L}$ of wastewater during the treatment at optimum condition followed by separation and drying process. It was found to be $1.07 \mathrm{~g} / \mathrm{L}$. The quantity of sludge development is not act of anode ingestion whereas the maximum amount of sludge is formed at the neutral $\mathrm{pH}$

\section{Field Emission Scanning Electron Microscope-Energy Dispersive Spectroscopy (FESEM-EDX) Analysis of Sludge}

The sludge and scum both were analyzed by scanning electron micrographs (SEM) to identify its morphological characteristics. As clearly shown in Figure 6(a) and Figure 7(a), the scum particles look like more even and porous in comparison to the sludge particles, which is due to floatation process which occurred during EC. On the other hand, sludge particles seem dense, which are suitable for the settling process. The variation of particle size in both sludge and scum varied $2-24$ and $2-19 \mu \mathrm{m}$ respectively in Figure 6(b) \& Figure 7(b) and found to be mostly amorphous in nature. In case of scum which particle seems big size, these may be due to aggregation of several particles otherwise all particle found to be less than $20 \mu \mathrm{m}$.

The EDAX analysis was performed for the confirmation of elemental constituent in sludge scum. Figure 8(a) indicates that the aluminum (43.24\%) and oxygen $(42.35 \%)$ content are in considerable amount followed by Manganese, chlorine, calcium, sulfur, carbon, sodium, silicon and phosphorus, all of which

Table 4. Characteristics of sludge.

\begin{tabular}{cc}
\hline Characteristics & Value $( \pm \mathrm{SD})$ \\
\hline $\mathrm{pH}$ & $7.93 \pm 0.15$ \\
Color & Dark brown \\
Moisture content $(\%)$ & $15.03 \pm 3.57$ \\
Sludge formation $(\mathrm{g} / \mathrm{L})$ & $1.07 \pm 0.03$ \\
Organic/inorganic ratio & $62 / 38 \pm \mathrm{NA}$
\end{tabular}




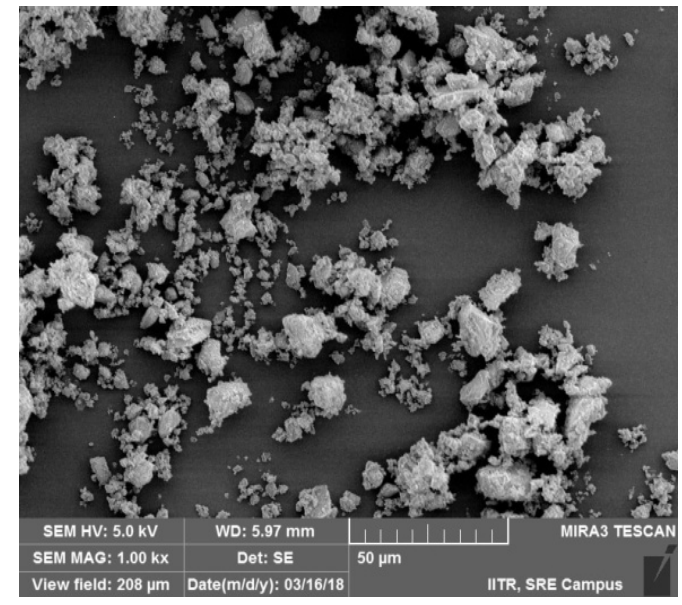

(a)

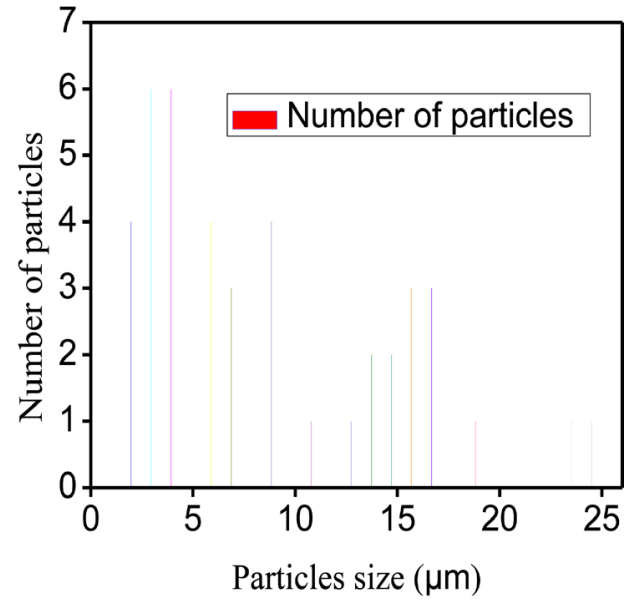

(b)

Figure 6. (a) FESEM analysis of sludge; (b) Particles size of sludge.

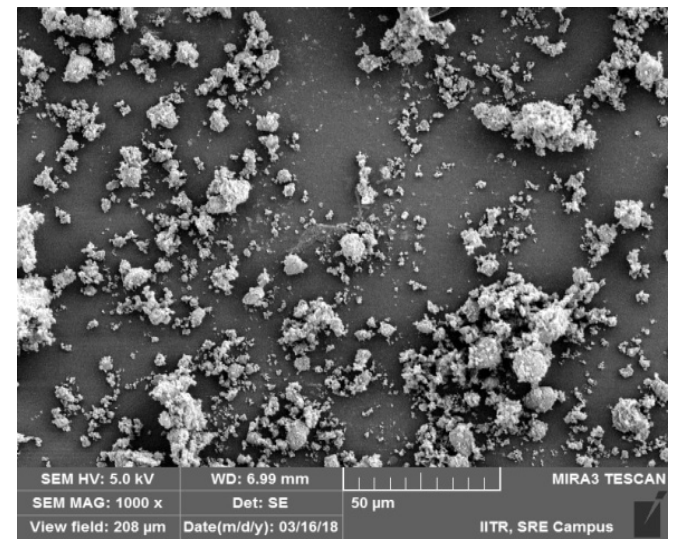

(a)

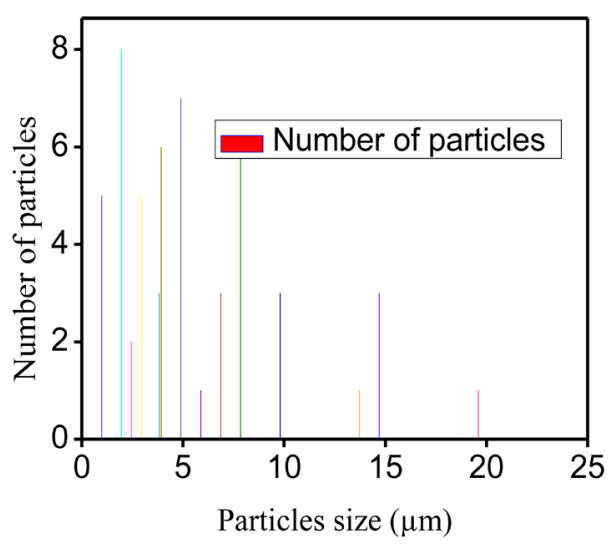

(b)

Figure 7. (a) FESEM analysis of scum; (b) Particles size of scum.

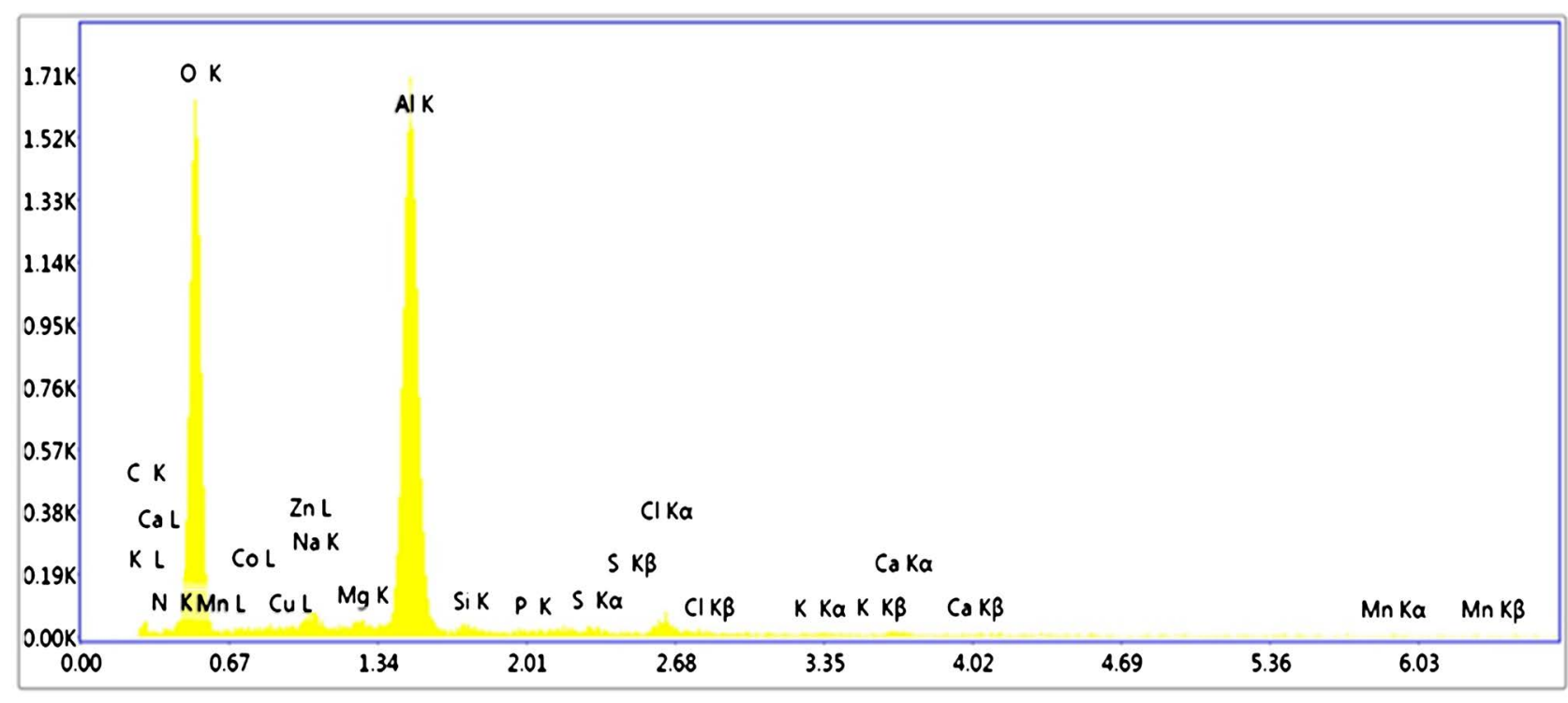

(a) 


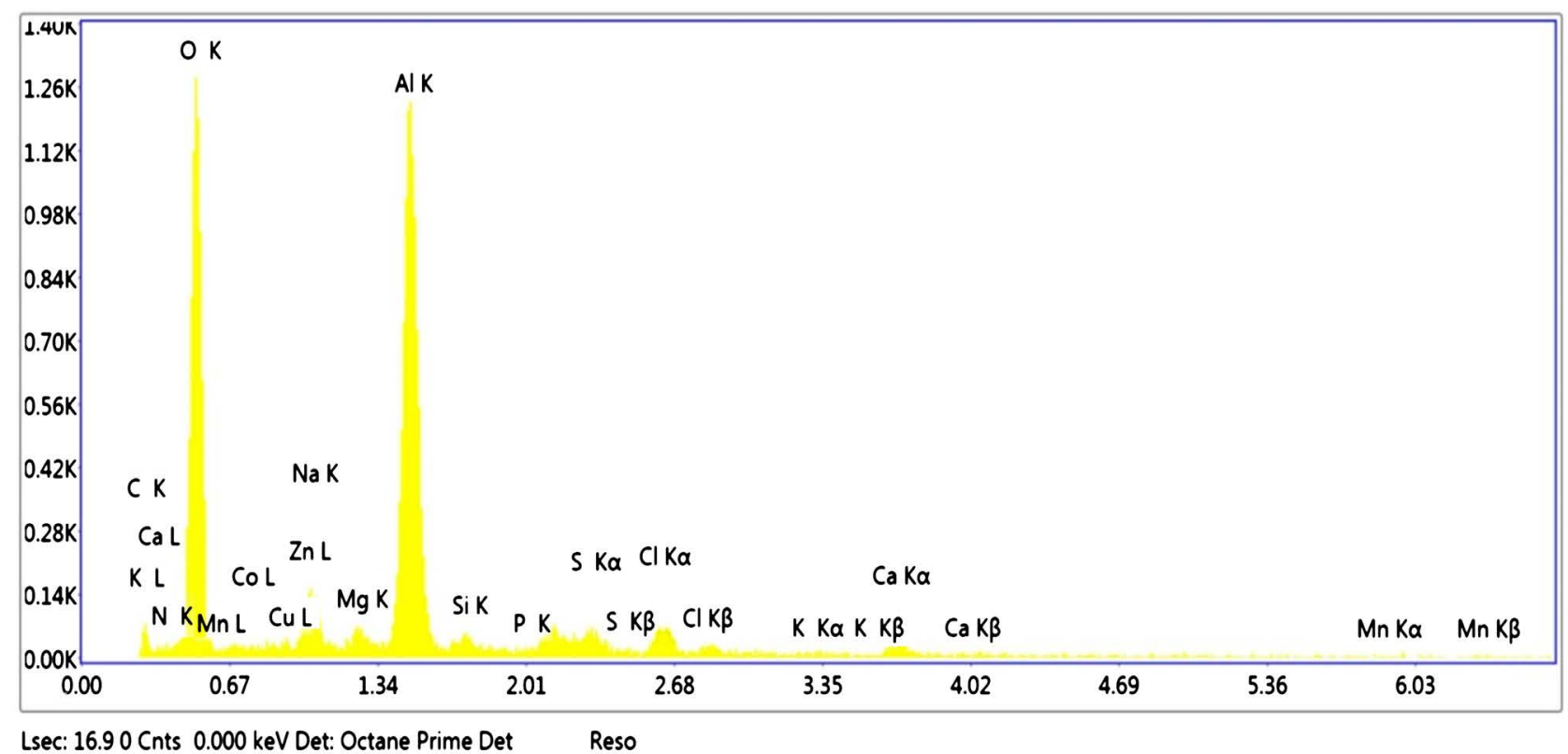

(b)

Figure 8. (a) \& (b) Images of EDAX analysis of sludge and scum.

were in the range of $(1 \%-3 \%)$ and rest were present in less than $1 \%$. On the other hand, Figure 8 (b) represent the scum, in which top content was oxygen (41.42\%) and aluminum (23.51\%) followed by calcium, sulfur, chlorine, sodium, manganese, magnesium nitrogen, zinc and silicon were present in the range of (1\% - 4\%) and leaving behind all other elements were less than 1\%. As aluminum content was seen to be present in good quantity in both sludge and scum, it can be recovered and applied for the removal of pollutants from wastewater [63]. Most of the essential elements mentioned as nutrients for the growth of plants are present in good amount in both sludge and scum. So, it is suitable to be used as blending material for compost process [32]. Nevertheless, further experimentation is needed for the composting process.

\section{Conclusion}

The encouraging results achieved from experiments show that the electrocoagulation is a promising process and has the potential to reduce the $\mathrm{BOD}, \mathrm{COD}$, Color, TOC and TDS from pulp and paper industry wastewater. The overall reduction in COD, Color, TOC and TDS was 70\%, 98\%, $68 \%$ and $41 \%$ respectively; biodegradability ratio enhanced up to 0.41 at $\mathrm{pH}=7.00$, current density $=$ 25.20 , time $=40 \mathrm{~min}$ and a dose of electrolyte $1 \mathrm{~g} / \mathrm{L}$ with $100 \mathrm{rpm}$ stirring speed. The analysis was repeated in triplicate and result showed the good repeatability in the error range of $2 \%-5 \%$. SEM-EDX analysis revealed that EC sludge can act as a potential nutrient for plants growth and can be used for several other purposes. All the physiochemical parameters of EC treated water were found below the permissible limit prescribed by WHO and CPCB; thus, can be used as an alternative to reduce the freshwater input in agriculture fields. 


\section{Acknowledgements}

The research grant for this study provided by the University Grant Commission, New Delhi, Government of India, is gratefully acknowledged

\section{Conflicts of Interest}

The authors declare no conflicts of interest regarding the publication of this paper.

\section{References}

[1] Anushree, A., Kumar, S. and Sharma, C. (2016) $\mathrm{Ce}_{1-\mathrm{x}} \mathrm{Co}_{\mathrm{x}} \mathrm{O}_{\mathrm{y}}$ Nanocatalysts: Synthesis, Characterization and Environmental Application. Catalysis Science \& Technology, 6, 2101-2111.

[2] Pokhrel, D. and Viraraghavan, T. (2004) Treatment of Pulp and Paper Mill Wastewater-A Review. Science of the Total Environment, 333, 37-58.

https://doi.org/10.1016/j.scitotenv.2004.05.017

[3] Peck, V. and Daley, R. (1994) Towards a "Greener" Pulp and Paper Industry. Environmental Science \& Technology, 28, 524A-527A.

[4] Karrasch, B., et al. (2006) Effects of Pulp and Paper Mill Effluents on the Microplankton and Microbial Self-Purification Capabilities of the Biobío River, Chile. Science of the Total Environment, 359, 194-208. https://doi.org/10.1016/j.scitotenv.2005.03.029

[5] Thompson, G., Swain, J., Kay, M. and Forster, C. (2001) The Treatment of Pulp and Paper Mill Effluent: A Review. Bioresource Technology, 77, 275-286. https://doi.org/10.1016/S0960-8524(00)00060-2

[6] Berryman, D., Houde, F., DeBlois, C. and O’Shea, M. (2004) Nonylphenolic Compounds in Drinking and Surface Waters Downstream of Treated Textile and Pulp and Paper Effluents: A Survey and Preliminary Assessment of Their Potential Effects on Public Health and Aquatic Life. Chemosphere, 56, 247-255. https://doi.org/10.1016/j.chemosphere.2004.02.030

[7] Simonič, M. and Vnučec, D. (2012) Coagulation and UF Treatment of Pulp and Paper Mill Wastewater in Comparison. Central European Journal of Chemistry, 10, 127-136. https://doi.org/10.2478/s11532-011-0121-8

[8] Mahesh, S., et al. (2016) Continuous Electrocoagulation Treatment of Pulp and Paper Mill Wastewater: Operating Cost and Sludge Study. RSC Advances, 6, 16223-16233. https://doi.org/10.1039/C5RA27486A

[9] Li, J., Hu, H., Song, Y. and Chai, X.-S. (2015) New Evidence for the Role of the Borohydride Pretreatment on the Hydrogen Peroxide Bleaching of Kraft Pulp. RSC Advances, 5, 98067-98074. https://doi.org/10.1039/C5RA17964E

[10] CPCB (2016) Final Document on Revised Classification of Industrial Sectors Central Pollution Control Board Delhi.

[11] Sharma, J., Mishra, I.M., Dionysiou, D.D. and Kumar, V. (2015) Oxidative Removal of Bisphenol A by UV-C/Peroxymonosulfate (PMS): Kinetics, Influence of Co-Existing Chemicals and Degradation Pathway. Chemical Engineering Journal, 276, 193-204. https://doi.org/10.1016/j.cej.2015.04.021

[12] Ciputra, S., Antony, A., Phillips, R., Richardson, D. and Leslie, G. (2010) Comparison of Treatment Options for Removal of Recalcitrant Dissolved Organic Matter from Paper Mill Effluent. Chemosphere, 81, 86-91. 
https://doi.org/10.1016/j.chemosphere.2010.06.060

[13] Singh, R., Prakash, A. and Balagurumurthy, B. (2015) Hydrothermal Liquefaction of Agricultural and Forest Biomass Residue: Comparative Study. Journal of Material Cycles and Waste Management, 17, 442-452.

https://doi.org/10.1007/s10163-014-0277-3

[14] Rana, R.S., Singh, P., Kandari, V., Singh, R., Dobhal, R. and Gupta, S. (2017) A Review on Characterization and Bioremediation of Pharmaceutical Industries' Wastewater: An Indian Perspective. Applied Water Science, 7, 1-12. https://doi.org/10.1007/s13201-014-0225-3

[15] Rajni, S., Satish, K. and Chhaya, S. (2011) Tertiary Treatment Option for Pulp and Paper Mill Wastewater to Achieve Effluent Recycling Tertiary Treatment Option for Pulp and Paper Mill Wastewater to Achieve Effluent Recycling. IPPTA, 23, 155-159.

[16] Sharma, R., Kumar, S. and Sharma, C. (2013) Influence of Operational Parameters on Electro Coagulation Process in Pulp and Paper Mill Effluent Treatment. Environmental Engineering and Management Journal, 13, 289-296. https://doi.org/10.30638/eemj.2014.033

[17] Ali, M. and Sreekrishnan, T.R. (2001) Aquatic Toxicity from Pulp and Paper Mill Effluents: A Review. Advances in Environmental Research, 5, 175-196. https://doi.org/10.1016/S1093-0191(00)00055-1

[18] Leiviskä, T., Nurmesniemi, H., Pöykiö, R., Rämö, J., Kuokkanen, T. and Pellinen, J. (2008) Effect of Biological Wastewater Treatment on the Molecular Weight Distribution of Soluble Organic Compounds and on the Reduction of BOD, COD and P in Pulp and Paper Mill Effluent. Water Research, 42, 3952-3960.

https://doi.org/10.1016/j.watres.2008.06.016

[19] Chen, G. (2004) Electrochemical Technologies in Wastewater Treatment. Separation and Purification Technology, 38, 11-41.

[20] Motoc, S., Manea, F., Pop, A., Pode, R. and Teodosiu, C. (2012) Electrochemical Degradation of Pharmaceutical Effluents on Carbon-Based Electrodes. Environmental Engineering and Management Journal, 11, 627-634.

[21] Daneshvar, N., Oladegaragoze, A. and Djafarzadeh, N. (2006) Decolorization of Basic Dye Solutions by Electrocoagulation: An Investigation of the Effect of Operational Parameters. Journal of Hazardous Materials, 129, 116-122. https://doi.org/10.1016/j.jhazmat.2005.08.033

[22] Kobya, M., Can, O.T. and Bayramoglu, M. (2003) Treatment of Textile Wastewaters by Electrocoagulation Using Iron and Aluminum Electrodes. Journal of Hazardous Materials, 100, 163-178. https://doi.org/10.1016/S0304-3894(03)00102-X

[23] Zaleschi, L., Teodosiu, C., Cretescu, I. and Andres Rodrigo, M. (2012) A Comparative Study of Electrocoagulation and Chemical Coagulation Processes Applied for Wastewater Treatment. Environmental Engineering and Management Journal, 11, 1517-1525.

[24] Garg, K.K. and Prasad, B. (2015) Electrochemical Treatment of Benzoic Acid (BA) from Aqueous Solution and Optimization of Parameters by Response Surface Methodology (RSM). Journal of the Taiwan Institute of Chemical Engineers, 56, 122-130. https://doi.org/10.1016/j.jtice.2015.04.005

[25] Bani-Melhem, K. and Smith, E. (2012) Grey Water Treatment by a Continuous Process of an Electrocoagulation Unit and a Submerged Membrane Bioreactor System. Chemical Engineering Journal, 198-199, 201-210. https://doi.org/10.1016/j.cej.2012.05.065

[26] Baş, D. and Boyacı, İ.H. (2007) Modeling and Optimization I: Usability of Response 
Surface Methodology. Journal of Food Engineering, 78, 836-845. https://doi.org/10.1016/j.jfoodeng.2005.11.024

[27] Ghosh, D., Solanki, H. and Purkait, M.K. (2008) Removal of Fe(II) from Tap Water by Electrocoagulation Technique. Journal of Hazardous Materials, 155, 135-143. https://doi.org/10.1016/j.jhazmat.2007.11.042

[28] Mollah, M.Y.A., Morkovsky, P., Gomes, J.A.G., Kesmez, M., Parga, J. and Cocke, D.L. (2004) Fundamentals, Present and Future Perspectives of Electrocoagulation.

[29] Uğurlua, M., Gürses, A., Doğar, Ç. and Yalçın, M. (2008) The Removal of Lignin and Phenol from Paper Mill Effluents by Electrocoagulation. Journal of Environmental Management, 87, 420-428. https://doi.org/10.1016/j.jenvman.2007.01.007

[30] El-Naas, M.H., Al-Zuhair, S., Al-Lobaney, A. and Makhlouf, S. (2009) Assessment of Electrocoagulation for the Treatment of Petroleum Refinery Wastewater. Journal of Environmental Management, 91, 180-185. https://doi.org/10.1016/j.jenvman.2009.08.003

[31] Faubert, P., Barnabé, S., Bouchard, S., Côté, R. and Villeneuve, C. (2016) Pulp and Paper Mill Sludge Management Practices: What Are the Challenges to Assess the Impacts on Greenhouse Gas Emissions? Resources, Conservation and Recycling, 108, 107-133. https://doi.org/10.1016/j.resconrec.2016.01.007

[32] Zodi, S., Potier, O. and Leclerc, J. (2009) Treatment of the Textile Wastewaters by Electrocoagulation: Effect of Operating Parameters on the Sludge Settling Characteristics. Separation and Purification Technology, 69, 29-36.

https://doi.org/10.1016/j.seppur.2009.06.028

[33] Drouiche, N., Aoudj, S., Hecini, M., Ghaffour, N., Lounici, H. and Mameri, N. (2009) Study on the Treatment of Photovoltaic Wastewater Using Electrocoagulation: Fluoride Removal with Aluminium Electrodes-Characteristics of Products. Journal of Hazardous Materials, 169, 65-69.

[34] Kim, D., et al. (2016) Characterization of Sludge Generated by Electrocoagulation for the Removal of Heavy Metals. Desalination and Water Treatment, 52.

[35] APHA (1998) Standard Methods for the Examination of Water and Wastewater. 20th Edition, American Public Health Association, American Water Works Association and Water Environmental Federation, Washington DC.

[36] Srivastava, S.P. and Srivastava, S.P. (2013) Solar Energy and Its Future Role in Indian Economy. International Journal of Environmental Science: Development and Monitoring, 4, 81-88.

[37] Zhang, S., Zhang, J., Wang, W., Li, F. and Cheng, X. (2013) Solar Energy Materials \& Solar Cells Removal of Phosphate from Landscape Water Using an Electrocoagulation Process Powered Directly by Photovoltaic Solar Modules. Solar Energy Materials and Solar Cells, 117, 73-80. https://doi.org/10.1016/j.solmat.2013.05.027

[38] Ortiz, J.M., Expósito, E., Gallud, F., García-García, V., Montiel, V. and Aldaz, A. (2006) Photovoltaic Electrodialysis System for Brackish Water Desalination: Modeling of Global Process. Journal of Membrane Science, 274, 138-149. https://doi.org/10.1016/j.memsci.2005.08.006

[39] Montiel, V., Aldaz, A., Valero, D., Ortiz, J.M. and Expo, E. (2008) Electrocoagulation of a Synthetic Textile Effluent Powered by Photovoltaic Energy without Batteries: Direct Connection Behaviour. Solar Energy Materials and Solar Cells, 92, 291-297.

[40] Park, H., Hoffmann, M.R., et al. (2008) Solar-Powered Production of Molecular Hydrogen from Water Coupled with Organic Compound Oxidation. The Journal of Physical Chemistry C, 112, 885-889. 
[41] Al Suleimani, Z. and Nair, V.R. (2000) Desalination by Solar-Powered Reverse Osmosis in a Remote Area of the Sultanate of Oman. Applied Energy, 65, 367-380. https://doi.org/10.1016/S0306-2619(99)00100-2

[42] Valero, D., Ortiz, J.M., Exposito, E., Montiel, V. and Aldaz, A. (2010) Electrochemical Wastewater Treatment Directly Powered by Photovoltaic Panels: Electrooxidation of a Dye-Containing Wastewater. Environmental Science \& Technology, 44, 5182-5187.

[43] Mahesh, S., Prasad, B., Mall, I.D. and Mishra, I.M. (2006) Electrochemical Degradation of Pulp and Paper Mill Wastewater. Part 1. COD and Color Removal. Industrial \& Engineering Chemistry Research, 45, 2830-2839.

[44] Chen, X., Chen, G. and Yue, P.L. (2000) Separation of Pollutants from Restaurant Wastewater by Electrocoagulation. Separation and Purification Technology, 19, 65-76. https://doi.org/10.1016/S1383-5866(99)00072-6

[45] Do, J.-S. and Chen, M.-L. (1994) Decolourization of Dye-Containing Solutions by Electrocoagulation. Journal of Applied Electrochemistry, 24, 785-790. https://doi.org/10.1007/BF00578095

[46] Zaied, M. and Bellakhal, N. (2009) Electrocoagulation Treatment of Black Liquor from Paper Industry. Journal of Hazardous Materials, 163, 995-1000.

[47] Vik, E.A., Carlson, D.A., Eikum, A.S. and Gjessing, E.T. (1984) Electrocoagulation of Potable Water. Water Research, 18, 1355-1360. https://doi.org/10.1016/0043-1354(84)90003-4

[48] Adhoum, N., Monser, L., Bellakhal, N. and Belgaied, J.-E. (2004) Treatment of Electroplating Wastewater Containing $\mathrm{Cu}^{2+}, \mathrm{Zn}^{2+}$ and $\mathrm{Cr}(\mathrm{VI})$ by Electrocoagulation. Journal of Hazardous Materials, 112, 207-213. https://doi.org/10.1016/j.jhazmat.2004.04.018

[49] Kapałka, A., Fóti, G. and Comninellis, C. (2010) Basic Principles of the Electro-Chemical Mineralization of Organic Pollutants for Wastewater Treatment. In: Comninellis, Christos and Chen, Eds., Electrochemistry for the Environment, Springer New York, New York, 1-23.

[50] Khansorthong, S. and Hunsom, M. (2009) Remediation of Wastewater from Pulp and Paper Mill Industry by the Electrochemical Technique. Chemical Engineering Journal, 151, 228-234. https://doi.org/10.1016/j.cej.2009.02.038

[51] Sridhar, R., Sivakumar, V., Prince Immanuel, V. and Prakash Maran, J. (2011) Treatment of Pulp and Paper Industry Bleaching Effluent by Electrocoagulant Process. Journal of Hazardous Materials, 186, 1495-1502. https://doi.org/10.1016/j.jhazmat.2010.12.028

[52] Inan, H., Dimoglo, A., Şimşek, H. and Karpuzcu, M. (2004) Olive Oil Mill Wastewater Treatment by Means of Electro-Coagulation. Separation and Purification Technology, 36, 23-31. https://doi.org/10.1016/S1383-5866(03)00148-5

[53] Marmanis, D., Dermentzis, K., Christoforidis, A., Ouzounis, K. and Moumtzakis, A. (2014) Electrochemical Treatment of Actual Dye House Effluents Using Electrocoagulation Process Directly Powered by Photovoltaic Energy. Desalination and Water Treatment, 56, 2988-2993.

[54] Un, U.T., Topal, S. and Ates, F. (2017) Electrocoagulation of Tissue Paper Wastewater and an Evaluation of Sludge for Pyrolysis. Desalination and Water Treatment, 57, 28724-28733.

[55] Kalyani, K.S.P., Balasubramanian, N. and Srinivasakannan, C. (2009) Decolorization and COD Reduction of Paper Industrial Effluent Using Electro-Coagulation. 
Chemical Engineering Journal, 151, 97-104.

https://doi.org/10.1016/j.cej.2009.01.050

[56] Bockris, J.O., Conway, B.E., Yeager, E. and White, R.E. (1981) Comprehensive Treatise of Electrochemistry: Electrochemical Processing. Springer, Berlin.

[57] Nassar, M.M., Fadaly, O.A. and Sedahmed, G.H. (1983) A New Electrochemical Technique for Bleaching Cellulose Pulp. Journal of Applied Electrochemistry, 13, 663-667. https://doi.org/10.1007/BF00617824

[58] Alverez-Gallegos, A. and Pletcher, D. (1999) The Removal of Low Level Organics via Hydrogen Peroxide Formed in a Reticulated Vitreous Carbon Cathode Cell. Part 2: The Removal of Phenols and Related Compounds from Aqueous Effluents. Electrochimica Acta, 44, 2483-2492. https://doi.org/10.1016/S0013-4686(98)00371-5

[59] Aboulhassan, M.A., Souabi, S. and Yaacoubi, A. (2008) Pollution Reduction and Biodegradability Index Improvement of Tannery Effluents. International Journal of Environmental Science and Technology, 5, 11-16. https://doi.org/10.1007/BF03325992

[60] Vigneswaran, S. and Sundaravadivel, M. (2004) Recycle and Reuse of Domestic Wastewater: Wastewater Recycle, Reuse, and Reclamation. Encyclopedia of Life Support Systems (EOLSS), Developed under the Auspices of the UNESCO, Eolss Publishers, Oxford. http://www.eolss.net

[61] Feldkirchner, D.C., Wang, C., Gower, S.T., Kruger, E.L. and Ferris, J. (2003) Effects of Nutrient and Paper Mill Biosolids Amendments on the Growth and Nutrient Status of Hardwood Forests. Forest Ecology and Management, 177, 95-116. https://doi.org/10.1016/S0378-1127(02)00318-3

[62] Abdullah, R., et al. (2015) Characterization and Feasibility Assessment of Recycled Paper Mill Sludges for Land Application in Relation to the Environment. International Journal of Environmental Research and Public Health, 12, 9314-9329. https://doi.org/10.3390/ijerph120809314

[63] Correia, A., et al. (2005) Municipal Wastewater Treatment with Anodizing Solid Waste. Desalination, 185, 341-350. 